\title{
Effect of removal of lambs or treatment with bromocriptine on plasma concentrations of prolactin and FSH during the post-partum period in ewes lambing at different times during the breeding season
}

\author{
B. P. Fitzgerald and F. J. Cunningham \\ Department of Physiology \& Biochemistry, The University of Reading, \\ Whiteknights, Reading, Berks RG6 2AJ, U.K.
}

\begin{abstract}
Summary. Daily determinations of FSH and prolactin in plasma were made for 10-12 weeks after parturition in ewes which lambed either in the middle of (December) or late in (February) the breeding season. Fluctuations in the plasma concentrations of FSH could not be related to the time after parturition or to the occurrence or otherwise of oestrus and ovulation. However, there was evidence of an increased secretion of prolactin post partum but only in those ewes which lambed in February. The lack of an elevated level of prolactin during the post-partum period in the December-lambing ewes was associated with an earlier return to oestrus by these animals. The suppression of prolactin concentrations by treatment with bromocriptine to undetectable values in the December-lambing ewes was not associated with an earlier return to oestrus. The removal of lambs at various times post partum from those ewes which lambed in February was not associated with any marked changes in prolactin secretion. The results suggest that when the plasma concentrations of prolactin are low post partum there is a greater likelihood of an earlier resumption of breeding activity in the ewe.
\end{abstract}

\section{Introduction}

The duration of post-partum anoestrus in the ewe is shortest in those ewes which lamb early rather than late in the breeding season (Hafez, 1952; Mauleon \& Dauzier, 1965). The difference stems from the fact that at the end of the breeding season the extent of post-partum anoestrus is confounded by the onset of seasonal anoestrus. It is, therefore, not unreasonable to predict that the pattern of secretion of follicle-stimulating hormone (FSH) and prolactin might also reflect this variation.

Since high circulating concentrations of prolactin may be significant in the suppression of reproductive activity post partum (Kann, Martinet \& Schirar, 1977, 1978a), it was considered appropriate to examine the effect of alterations in the circulating concentrations of prolactin on the restoration of reproductive activity post partum. It was envisaged that the secretion of prolactin could be manipulated by the removal of lambs or the injection of bromocriptine, a potent inhibitor of prolactin secretion. 
Materials and Methods

\section{Experiment 1}

Animals. Pregnant ewes ( 7 Finnish Landrace $\times$ Dorset Horn and 7 Dorset Horn) were selected at random from 2 independent flocks and kept as a single flock in an open shed from 15 December 1975 (Day 100 of pregnancy) until the end of the experiment on 26 April 1976. They were fed a diet of concentrates and hay and water was freely available. The ewes lambed between 26 January 1976 and 13 February 1976, i.e. towards the end of the breeding season.

Treatments. After parturition lambs were removed from the ewes at $24 \mathrm{~h}(\mathrm{~N}=2)$ or at $3(\mathrm{~N}=4), 6(\mathrm{~N}=3)$ and 9 weeks $(\mathrm{N}=3)$ or remained with the ewe for the duration of the study. Lambs were given free access to creep feed even when they were still being suckled.

\section{Experiment 2}

Animals. Finnish Landrace $\times$ Dorset Horn $\times$ Scottish Blackface ewes $(\mathrm{N}=25)$ were selected at random. Oestrus was synchronized with intravaginal pessaries impregnated with $60 \mathrm{mg}$ medroxyprogesterone acetate (Upjohn Ltd). Pessaries were inserted on 14 July 1976 and 12 days later each ewe was given an intramuscular injection of 750 i.u. PMSG (Apocrine: Bayer). The pessaries were withdrawn $48 \mathrm{~h}$ later and the ewes mated with a fertile ram fitted with harness and marking crayon. From Day 100 of pregnancy the 24 ewes that conceived were housed and fed as described in Exp. 1. The ewes lambed between 20 and 26 December 1976 ; i.e. in the middle of the breeding season.

Treatments. Immediately after parturition 21 ewes were allocated at random to 1 of 3 groups of 7 each. Group 1 ewes were injected subcutaneously twice daily at 09:00 and 21:00 h, beginning $24-36 \mathrm{~h}$ after parturition, with bromocriptine (1 mg) for 8-10 weeks to avoid suppression of milk secretion (Kann et al., 1978b). Bromocriptine (2-bromo-alpha-ergocriptinemesylate: Sandoz Ltd) was dissolved in a few drops of $70 \%$ ethanol and the volume adjusted with $0.9 \%(\mathrm{w} / \mathrm{v})$ saline to a final concentration of $1 \mathrm{mg} / \mathrm{ml}$. The remaining ewes were injected with saline twice daily (Group 2) or received no treatment (Group 3). All the ewes suckled either one or two lambs. In addition the lambs were given free access to creep feed at all times.

\section{Collection of blood samples}

In both experiments blood $(10 \mathrm{ml})$ was collected daily between 09:00 and 10:00 $\mathrm{h}$ by jugular venepuncture. The blood was placed immediately in tubes kept in ice and centrifuged within $30 \mathrm{~min}$ of collection at $1500 \mathrm{~g}$ for $10 \mathrm{~min}$. The plasma was separated and stored at $-20^{\circ} \mathrm{C}$ until assay.

\section{Detection of oestrus and ovulation}

Oestrus was detected by constantly exposing the ewes to a vasectomized ram fitted with harness and marking crayon. The ewes were inspected daily at 09:00 h for evidence of mating. The concentration of progesterone in plasma was measured 2-3 times a week. Ovulation was assumed to have occurred if the concentration of progesterone rose to $>0.5 \mathrm{ng} / \mathrm{ml}$ plasma and was sustained for 2-6 days.

\section{Radioimmunoassays}

Plasma concentrations of FSH, prolactin and progesterone were measured by the assays described previously (McNeilly, McNeilly, Walton \& Cunningham, 1976; Walton, McNeilly, McNeilly \& Cunningham, 1977; Walton, Evins, Fitzgerald \& Cunningham, 1980). However, a 
different prolactin standard was used (NIH-prolactin-S6) and the sensitivity of the assay $\left(\mathrm{B} / \mathrm{B}_{\mathrm{o}}=90 \%\right)$ was $1.4 \mathrm{ng} \mathrm{NIH}-\mathrm{P}-\mathrm{S} 6 / \mathrm{ml}$. For any hormone, all plasma samples from each animal were assayed together in a single assay and estimations were made in duplicate. The precision of the assays, as reflected by the intra- and inter-assay coefficients of variation, was always $<10 \%$.

\section{Statistical analysis}

Statistical comparisons were carried out using Student's $t$ test.

\section{Results}

\section{Experiment 1}

Occurrence of oestrus and ovulation. During the first 12 weeks post partum the plasma concentrations of progesterone in 10 of the 14 ewes did not exceed $0.5 \mathrm{ng} / \mathrm{ml}$ and it was concluded that in these ewes ovulation did not occur. In the remaining 4 ewes which suckled 1 or 2 lambs for $3(\mathrm{~N}=1), 6(\mathrm{~N}=1)$ or 9 weeks $(\mathrm{N}=1)$ or throughout the experiment $(\mathrm{N}=1)$ increased concentrations of progesterone suggested that ovulation occurred on 1-4 occasions (Text-fig. 1). There was no suggestion that the removal of the lambs at the various times post

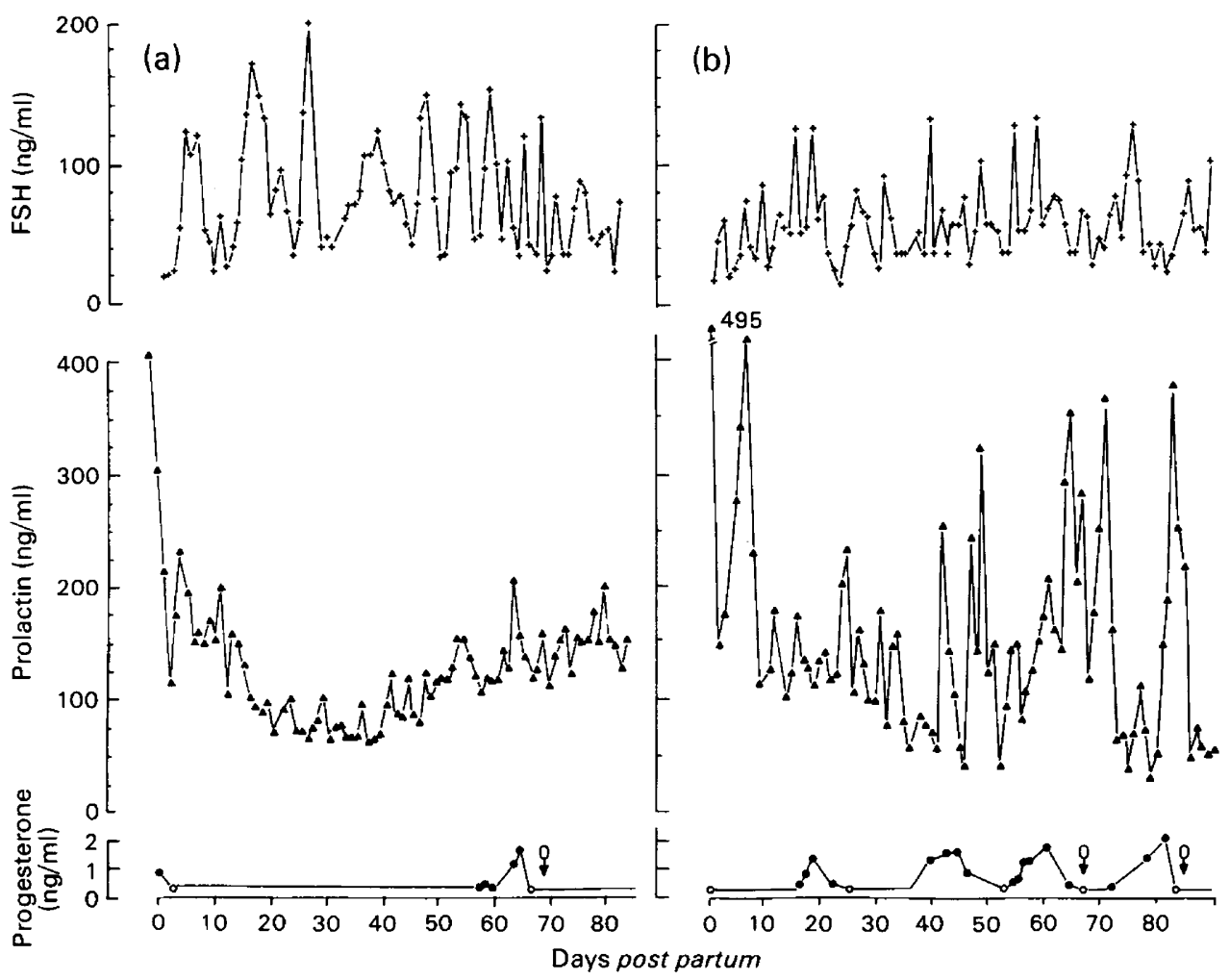

Text-fig. 1. Plasma concentrations of FSH, prolactin and progesterone during the post-partum period of ewes lambing at the end of the breeding season (February): (a) ewe suckling 2 lambs for 9 weeks and (b) ewe suckling 1 lamb for 3 weeks. The open circle (O) followed by a straight line indicates that during this period plasma concentrations of progesterone were $<0.5 \mathrm{ng} / \mathrm{ml}$. The day of oestrus is indicated $(\mathrm{O})$. 
partum was associated with an earlier return to oestrus. The progesterone profile associated with the first ovulation post partum was not characteristic of that found in ewes exhibiting regular oestrous cycles because increased concentrations were only observed for approximately 8-10 days (Text-fig. 1). Ovulation was accompanied by behavioural oestrus in 2 ewes on Days 67 and 69 post partum respectively.

Hormone profiles post partum. Examples of typical hormonal profiles obtained in 2 ewes during the post-partum period are shown in Text-fig. 1. The concentrations of prolactin in plasma were maximal on the day of parturition and ranged between 121 and $792 \mathrm{ng} / \mathrm{ml}$ $(412 \pm 48$ (s.e.m.) $\mathrm{ng} / \mathrm{ml}, \mathrm{N}=14$ ). Thereafter, day-to-day fluctuations were evident but there was a marked decrease from the high concentration seen at parturition to values which ranged between $59 \pm 7$ (s.e.m., $N=14$ ) on Day 35 and $94 \pm 16$ (s.e.m., $N=13$ ) $\mathrm{ng} / \mathrm{ml}$ plasma on Day 42 post partum. During the first 20 days post partum plasma concentrations of prolactin were less in the ewes from which lambs had been removed than in ewes which suckled. For example, the mean plasma concentration of prolactin in 19 samples collected during the first 10 days post partum from 2 ewes from which lambs were removed at $24 \mathrm{~h}$ post partum was $91 \pm 10$ ( \pm s.e.m.) $\mathrm{ng} / \mathrm{ml}$ whereas during the same period in 12 ewes which suckled the mean concentration in 119 samples was $224 \pm 11$ ( \pm s.e.m.) $\mathrm{ng} / \mathrm{ml}$. No significant differences in plasma concentrations of prolactin were found between ewes which suckled one or more lambs and ewes which did or did not suckle at any other time post partum. In most ewes there was a further increase in the plasma concentrations of prolactin from the low levels observed between Days 25 and 42 post partum and the mean daily concentration ranged between $132 \pm 17$ ( \pm s.e.m., $\mathrm{N}=14)$ at Day 61 and $215 \pm 62( \pm$ s.e.m., $\mathrm{N}=3) \mathrm{ng} / \mathrm{ml}$ at Day 74 post partum (Text-fig. 1).

At parturition the plasma concentrations of FSH in 7 ewes were below the detection limit of the assay $(<15 \mathrm{ng} \mathrm{NIH-FSH}-\mathrm{S} 8 / \mathrm{ml}$ ) but in 5 other ewes ranged between 20 and $49 \mathrm{ng} / \mathrm{ml}$. In the first 5-10 days post partum the concentrations of FSH in plasma gradually increased and ranged between 40 and $158 \mathrm{ng} / \mathrm{ml}$ at Day 10 . Thereafter, considerable day-to-day variations in concentration were observed and there was no suggestion of an overall change during the experimental period (Text-fig. 1).

\section{Experiment 2}

Occurrence of oestrus and ovulation. In all of the 21 ewes studied during the first 10 weeks post partum, plasma concentrations of progesterone $>0.5 \mathrm{ng} / \mathrm{ml}$ were detected in $2-6$ successive samples. Although increased progesterone concentrations of this order of magnitude do not constitute unequivocal evidence that ovulation occurred, the data have been interpreted to be indicative of luteal activity.

Oestrus was exhibited at $47 \pm 3$ days ( \pm s.e.m., $N=19$ ) post partum but there was no significant difference between the three treatment groups. There was considerable variation between the ewes in the number of ovulations which preceded the occurrence of oestrus and 13, 4 and 2 ewes ovulated once, twice and three times, respectively, before the occurrence of the ovulation that was accompanied by behavioural oestrus.

Hormone profiles post partum. In 20 of the ewes sampled on the day of parturition plasma concentrations of prolactin were high and ranged between 59 and $847 \mathrm{ng} / \mathrm{ml}$. Characteristic examples of the hormone profiles during the post-partum period are shown in Text-figs 2 and 3 . In the remaining ewe, however, the prolactin concentration did not exceed $16 \mathrm{ng} / \mathrm{ml}$.

In 7 of the ewes of Group 1 treatment with bromocriptine reduced the plasma concentration of prolactin to a low level which in all ewes was $<1.4 \mathrm{ng} / \mathrm{ml}$, although occasionally small elevations not exceeding $22 \mathrm{ng} / \mathrm{ml}$ were observed (Text-fig. 3). No differences were detected in the pattern of prolactin secretion in the saline-treated and untreated controls. In 10 out of the 14 ewes that did not receive bromocriptine the concentrations of prolactin were low for 2 or 3 

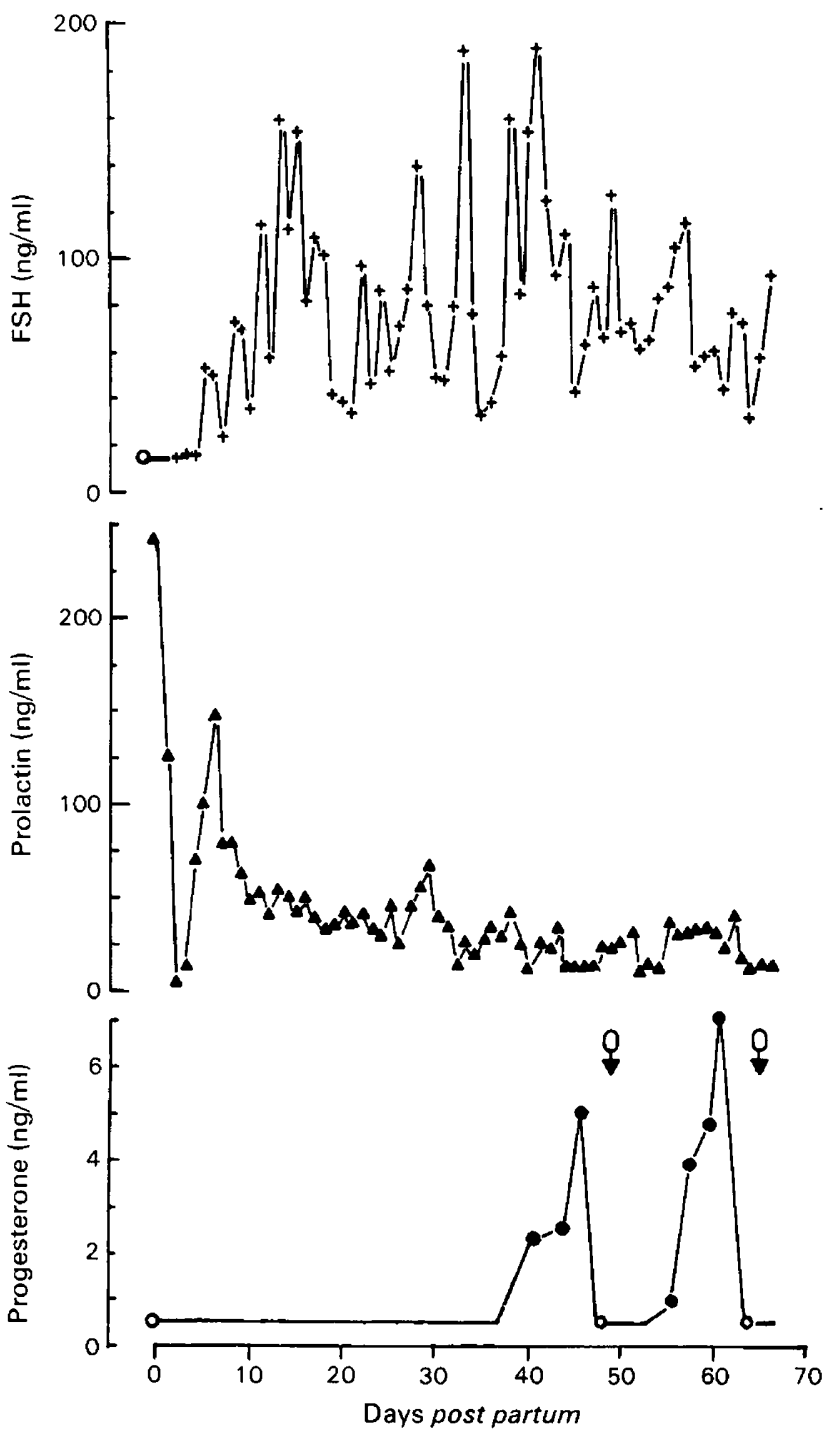

Text-fig. 2. Plasma concentrations of FSH, prolactin and progesterone in a ewe treated with saline (Exp. 2, Group 2) and suckling 2 lambs throughout the post-partum period after lambing in the middle of the breeding season (December). The open circle $(O)$ followed by a straight line indicates that during this period plasma FSH concentrations were below the detection limits of the assay and that progesterone values were $<0.5 \mathrm{ng} / \mathrm{ml}$ plasma. The day of oestrus is indicated $(\mathrm{O})$.

consecutive days during the first 10 days post partum (Text-fig. 2) and ranged between 2 and $50 \mathrm{ng} / \mathrm{ml}$, but in 2 of these ewes, the values on Days 2 and 7 post partum respectively were similar to those found in the bromocriptine-treated ewes and remained below $1.4 \mathrm{ng} / \mathrm{ml}$. In each of the 10 ewes the concentrations of prolactin gradually increased after Day 10 post partum but the maximum concentration reached varied amongst ewes; in 7 ewes the concentration fluctuated around $50 \mathrm{ng} / \mathrm{ml}$ and in 3 it reached about $100 \mathrm{ng} / \mathrm{ml}$. The pattern of prolactin secretion in the remaining 4 ewes indicated a gradual decline in concentrations from a high level at parturition to a lower, more stable baseline $(100-150 \mathrm{ng} / \mathrm{ml})$ at about Day 15 post partum (3 ewes) or, in 1 ewe, remained elevated throughout the entire period of the study. 


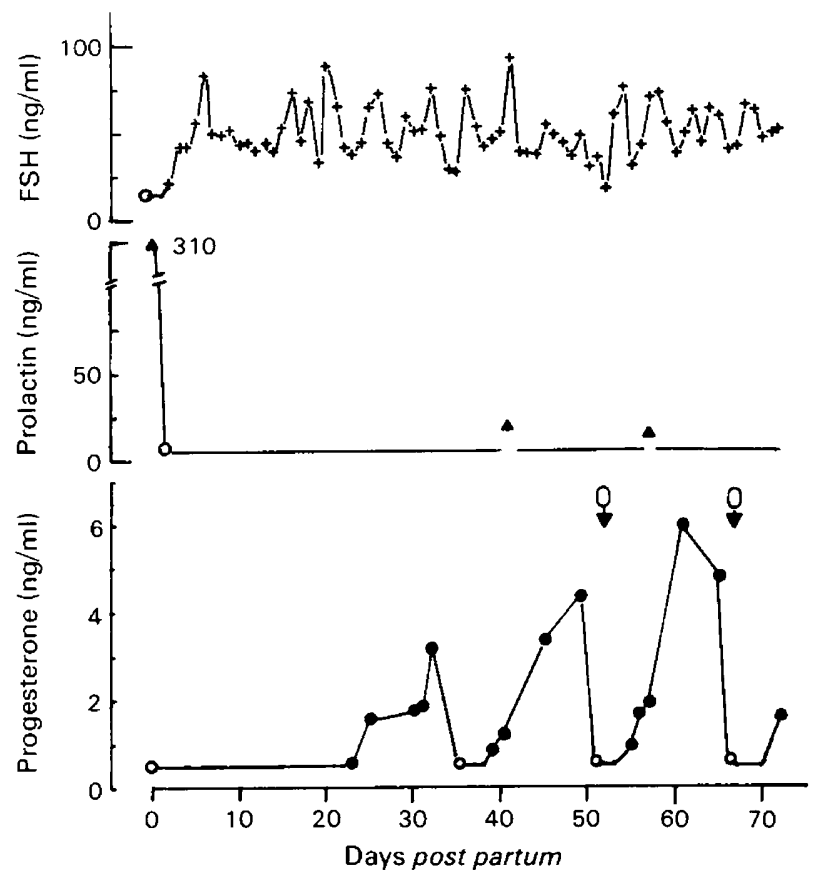

Text-fig. 3. Plasma concentrations of FSH, prolactin and progesterone in a ewe treated with bromocriptine (Exp. 2, Group 1) and suckling 2 lambs throughout the post-partum period after lambing in the middle of the breeding season (December). The open circle $(O)$ followed by a straight line indicates that during this period plasma concentrations of FSH and prolactin were below the detection limits of the assay, and that progesterone values were $<0.5 \mathrm{ng} / \mathrm{ml}$ plasma. The day of oestrus is indicated $(\mathrm{O})$.

No apparent differences in milk secretion between the treatment groups were observed at any time post partum since the body weights of the lambs in each group were similar.

The concentrations of FSH in plasma on the day of the parturition were $<15 \mathrm{ng} / \mathrm{ml}$ in 14 ewes and $15-51 \mathrm{ng} / \mathrm{ml}$ in the other 7 ewes. After parturition the concentration of FSH in plasma gradually increased to $20-195 \mathrm{ng} / \mathrm{ml}$ at Day 10 post partum and thereafter considerable day-to-day fluctuations in concentration were observed in individual ewes (Text-figs 2 and 3), as found in Exp. 1.

\section{Discussion}

The absence of oestrus and ovulation in the majority of the ewes during the first 12 weeks post partum, when parturition occurred at the end of the breeding season (Exp. 1), probably reflects the fact that lactational and seasonal anoestrus overlapped. On the other hand, when parturition was arranged to occur in the middle of the breeding season (Exp. 2), i.e. when the effect of seasonal anoestrus was minimal, lactation did not appear greatly to suppress the resumption of reproductive activity post partum. The interval from parturition to the resumption of reproductive activity is known to be dependent on the time of lambing during the breeding season (Mauleon \& Dauzier, 1965; Hunter, 1968).

Notwithstanding the limitations of progesterone concentrations as a reliable index of ovulation it is likely that in 4 ewes ovulation occurred on one or more occasions after parturition at the end of the breeding season and in 2 of these ewes ovulation was accompanied by the behavioural manifestations of oestrus. The integration of the factors which bring about the 
resumption of reproductive activity post partum probably represents a delicately balanced control system which does not manifest itself in all ewes at the same time. The integration of the system appears to be dependent on the time of occurrence of parturition since all the ewes which lambed in the middle of the breeding season ovulated within 10 weeks post partum and in $90 \%$ of these ovulation was accompanied by oestrus. Nevertheless, the fact that 1-3 ovulations occurred before oestrus supports the view that the expression of the control system is variable between ewes. The occurrence of repeated ovulations without the accompanying behavioural manifestations of oestrus during the post-partum period might be accounted for by the fact that in some ewes after the first ovulation post partum progesterone levels were not sustained but quickly returned to basal levels. In these cases, however, it is conceivable that the raised concentrations of progesterone in plasma might be related to a premature luteinization of a potentially ovulable follicle rather than to a true ovulation.

A notable feature of the results was that the majority of untreated ewes (Exp. 2, Groups 2 and 3 ), in which parturition occurred in the middle of the breeding season, had lower prolactin levels than did ewes which lambed towards the end of the breeding season. This observation supports previous studies demonstrating seasonal changes in prolactin secretion in lactating (Rhind, Robinson, Chesworth \& Crofts, 1980) and non-lactating (Walton et al., 1977) ewes. In all likelihood these differences in prolactin secretion post partum could be accounted for by an effect of daylength. Since in those ewes which lambed in the middle of the breeding season the prevailing photoperiod was one of short days, this meant that the environmental conditions were more suited to a low level of prolactin than in the first experiment when increasing daylength was associated with an elevation in the plasma concentration of prolactin and the onset of seasonal anoestrus. Clearly, therefore, the time of occurrence of parturition during the breeding season determines not only the duration of post-partum anoestrus but also the absolute levels of prolactin. Furthermore, the removal of lambs, as in the present study, would not be associated with any marked changes in prolactin secretion since this would be counteracted by the overriding effects of daylength.

In contrast to the study of Kann et al. (1977), treatment of ewes with bromocriptine, with the consequent suppression of prolactin secretion, was not associated with a reduction in the post-partum interval to oestrus in those ewes which lambed in the middle of the breeding season. These findings, however, are not necessarily at variance with those of Kann et al. (1977), because the concentrations of prolactin in those ewes not treated with bromocriptine were also low compared with those found in ewes in which parturition occurred towards the end of the breeding season. Probably, therefore, treatment with bromocriptine is effective in reducing the interval to the resumption of oestrous cycles post partum only when plasma concentrations of prolactin are elevated.

In the present study there was little suggestion that the plasma concentrations of FSH fluctuated in accordance with the occurrence of oestrus or ovulation and no changes which could be related to bromocriptine treatment or to the stage of lactation were observed. The wide day-to-day variation in the concentrations of FSH have been previously reported for anoestrous ewes (Walton et al., 1977) and for ewes during the oestrous cycle (McNeilly et al., 1976) and in early lactation (Kann et al., 1978a). It is possible, therefore, that FSH plays a permissive role in the regulation of reproductive activity post partum.

The results of this study are consistent with the hypothesis that high plasma concentrations of prolactin are associated with an absence of reproductive activity post partum. Since, however, the blood levels of prolactin could be either the cause or the effect of the observed differences in the duration of post-partum anoestrus, a firm conclusion as to the role of the hormone in the regulation of reproductive activity cannot be made.

We thank the staff of the University Farm, Sonning, Berkshire, for care of the animals: Dr S. S. Lynch and Dr B. J. A. Furr for antisera to human FSH and to progesterone: and 
N.I.A.M.D.D., Bethesda, Maryland, purified hormones. B.P.F. was in receipt of a Meat and Livestock Commission's Scholarship during the course of this work.

\section{References}

Hafez, E.S.E. (1952) Studies on the breeding season and reproduction of the ewe. J. agric Sci., Camb. 42, $189-265$.

Hunter, G.L. (1968) Increasing the frequency of pregnancy in sheep. Anim. Breed. Abstr. 36, 347-378.

Kann, G., Martinet, J. \& Schirar, A. (1977) Modifications of gonadotrophin secretion during natural and artificial hyperprolactinaemia in the ewe. In Prolactin and Human Reproduction, pp. 47-59. Eds P. G. Crosignani \& C. Robyn. Academic Press, London.

Kann, G., Martinet, J. \& Schirar, A. (1978a) Hypothalamic-pituitary control during lactation in sheep. In Control of Ovulation, pp. 319-333. Eds D. B. Crighton, N. B. Haynes, G. R. Foxcroft \& G. E. Lamming. Butterworths, London.

Kann, G., Carpentier, M.-C., Fevre, J., Martinet, J., Maubon, M., Meusnier, C., Paly, J. \& Vermeire, N. (1978b) Lactation and prolactin in sheep, role of prolactin in initiation of milk secretion. In Progress in Prolactin Physiology and Pathology, pp. 201-202. Eds C. Robyn \& M. Harter. Elsevier/North Holland, Amsterdam.
Mauleon, P. \& Dauzier, L. (1965) Variations de duree de l'anoestrus de lactation chez les brebis de race Ile-de-France. Annls Biol. anim. Biochim. Biophys. 5, 131-143.

McNeilly, J.R., McNeilly, A.S., Walton, J.S. \& Cunningham, F.J. (1976) Development and applica tion of a heterologous radioimmunoassay for ovine follicle-stimulating hormone. J. Endocr. 70, 69-79.

Rhind, S.M., Robinson, J.J., Chesworth, J.M. \& Crofts, R.M.J. (1980) Effects of season, lactation and plane of nutrition on prolactin concentrations in ovine plasma and the role of prolactin in the control of ewe fertility. J. Reprod. Fert. 58, 145-152.

Walton, J.S., McNeilly, J.R., McNeilly, A.S. \& Cunningham, F.J. (1977) Changes in concentrations of follicle-stimulating hormone, luteinizing hormone, prolactin and progesterone in the plasma of ewes during the transition from anoestrus to breeding activity. $J$. Endocr. 75, 127-136.

Walton, J.S., Evins, J.D., Fitzgerald, B.P. \& Cunningham, F.J. (1980) Abrupt decrease in daylength and short-term changes in the plasma concentrations of FSH, LH and prolactin in anoestrous ewes. J. Reprod. Fert. 59, 163-171.

Received 24 April 1980 